\title{
MIĘDZY POLITYKA A A POLITYCZNOŚCIĄ. ANALIZA DYSKURSÓW POLITYCZNYCH Z PUNKTU WIDZENIA (KULTUROWEJ) EKONOMII POLITYCZNEJ
}

\author{
Abstract \\ In between the politics and the political: Analysis of political discourses \\ from the point view of (cultural) political economy
}

The concept of post-politics, that dominated the contemporary public discourse, both from practical and theoretical approach, appears generally in two contexts, first related to the separation of power and politics (removal of the concept of the political from political discourse), second related to the process of moving away from the ideology (the end of ideology) in favour of a more pragmatic or/and consensual approach to politics or solving social conflict. The article focus in particular on the difference in between the post-politics and the political, within the context described by Carl Schmitt and Chantal Mouffe, both in refers to theoretical paradigm and practical politics, and its consequences from the point view of 'cultural political economy' (Bob Jessop, Ngai Ling Sum).

Keywords: the political, post-politics, (cultural) political economy, hegemony of neoliberal discourse, trilemma of globalisation

\section{Streszczenie}

Pojęcie postpolityki, które zdominowało współczesny dyskurs publiczny, zarówno praktyczno-polityczny, jak i teoretyczny, pojawia się zasadniczo w dwóch kontekstach, pierwszy związany jest z rozdzieleniem władzy i polityki (usunięciem z dyskursu politycznego pojęcia polityczności), drugi - z procesem odideologizowania polityki (końca ideologii) na rzecz bardziej pragmatycznego lub konsensualnego podejścia do uprawiania polityki czy rozwiązywania konfliktów społecznych. Niniejszy artykuł koncentruje się na podkreśleniu różnicy między postpolityką a politycznością, definiowanych przez Carla Schmitta i Chantal Mouffe tak w odniesieniu do paradygmatów teoretycznych, jak i praktyczno-politycznych, oraz ich konsekwencji z punktu widzenia „kulturowej ekonomii politycznej” (Bob Jessop, Ngai Ling Sum).

Słowa kluczowe: polityczność, postpolityka, (kulturowa) ekonomia polityczna, hegemonia dyskursu neoliberalnego, trylemat globalizacji 


\section{Definiowanie polityki - dyskursy teoretyczne a praktyczno-polityczne}

W dyskursie naukowym i coraz częściej w dyskursie publicznym pojawia się przekonanie, że współcześnie w polityce mamy do czynienia z postpolitycznością. Pojęcie to, przywoływane i odmieniane przez wszystkie przypadki w różnych kontekstach, stało się jednym z modnych obecnie słów kluczy używanych do opisu politycznej rzeczywistości, które stosowane do wszystkiego, w rezultacie niczego nie wyjaśniają. Zagadnienia polityki, postpolityki czy polityczności znajdują się dziś w polu zainteresowania wielu różnych ideologii czy dyscyplin naukowych, $\mathrm{z}$ których każda w ramach własnego pola semantycznego definiuje je na swój sposób (w rezultacie uzyskujemy odmienne wartości czy modele wyjaśniające zbudowane wokół odmiennych pojęć wraz z towarzyszącą im odmienną metodologią). Swoista wieloznaczność czy wielokontekstowość tych pojęć utrudnia porozumienie zarówno między teoretykami i praktykami (dyskursami teoretycznymi i praktyczno-politycznymi), jak i między samymi praktykami czy politykami różnych orientacji, ułatwia jednak ich użycie w celu porządkowania dominujących narracji współczesnych przeobrażeń: społecznych, gospodarczych czy kulturowych.

Niejednoznaczność czy nieokreśloność tych terminów powstaje zwykle na styku tzw. potocznych dyskursów czy języka (uproszczonych wyobrażeń na temat polityki) i dyskursów ,politycznych” - zarówno naukowych (teoretycznych), które stanowią narzędzie opisu i wyjaśniania czy krytyki praktyki politycznej, jak i praktyczno-politycznych, często postrzeganych w kategoriach czysto pragmatycznych jako środek perswazji, gry politycznej czy walki.

Pierwsze zderzenie (short circuit) $)^{1}$ pojawia się na styku dyskursów: języka potocznego i „politycznego" - zderzenie wyobrażeń ${ }^{2}$ o polityce z postrzeganą rzeczywistością prowadzi do różnego definiowania i rozumienia pojęć „polityka”, ,polityczność” czy „postpolityka”. Jak zauważa Andrzej Czajkowski [2011] w swoim artykule Polityka w pięciu odstonach. Metatypologia zjawiska, w potocznym dyskursie często pojawia się rozróżnienie między polityką a sprawowaniem

${ }^{1}$ Ulubiona metafora Słavoja Žižka [2011a] - w swojej autorskiej serii wydawniczej „Short Circuits” (Krótkie spięcia) pisze we wstępie: „do krótkiego spięcia dochodzi wtedy, kiedy w sieci znajduje się właściwie połączenie - wadliwe, oczywiście z punktu widzenia jej płynnego funkcjonowania. Czy zatem wstrząs wiążący się z krótkim spięciem nie jest jedną z najlepszych metafor krytycznej interpretacji? Czy nie jest tak, że jedną z najbardziej skutecznych procedur stanowi połączenie tych przewodów, które się zazwyczaj nie stykają ze sobą?" [Žižek, 2011a: 9].

2 Pojęcie wyobrażeń (imaginaries) jest kluczowe dla kulturowej ekonomii politycznej [Jessop, Sum, 2006] - definiowane jako rodzaj konceptualnej ramy (paradygmatu), sposób, w jaki postrzegamy otaczającą nas rzeczywistość, istotny dla naszej zdolności funkcjonowania w świecie. Zgodnie z kulturową ekonomią polityczną nie potrafimy postrzegać świata w całej jego złożoności i współzależności w rzeczywistym czasie, w rezultacie mamy potrzebę upraszczać lub redukować (przez przyjęcie określonych ideologii czy wyobrażeń), żeby cokolwiek rozumieć i być w stanie w nim funkcjonować, mniej lub bardziej skutecznie. Problem w tym, że zwykle między ideologią czy wyobrażeniem/wyobrażeniami (imaginary/imaginaries) a rzeczywistością pojawiają się poważne luki (nieciągłości, niejasności, nieścisłości). 
władzy, które w tym kontekście postrzegane jest bardziej jako zarządzanie czy administrowanie. W rezultacie w mediach słyszymy o „rządach polityków” lub „rządach apolitycznych ekspertów czy technokratów”. Co ciekawe, to rozróżnienie jest często przywoływane przez samych polityków, którzy zarzucają sobie nawzajem ,polityczność” lub przypisują ,,apolityczność”, oskarżając przeciwników o ,prowadzenie gry politycznej” czy ubolewając nad „upolitycznieniem wyborów”3. W tym kontekście negatywne konotacje związane z polityką, często utożsamiane z ,partyjnością polityki/polityków” lub ,polityką dla samej polityki”, uprawianej w celu zdobycia czy utrzymania władzy (przy czym to, co polityczne, stało się synonimem korzyści własnej), przeciwstawia się neutralnym lub apolitycznym ekspertom czy politykom, nawołując tym samym do odpolitycznienia polityki: prowadzenia „,apolitycznej polityki” czy „polityki bez polityki” [Czajkowski 2011].

Ta negatywna konotacja polityki czy polityczności wyraźnie wskazuje na kryzys zaufania społecznego do polityki i polityków oraz sprzeciw wobec aktualnie uprawianej polityki (prowadzenia jałowych sporów czy odgrywania spektakli medialnych, które niczemu nie służą), a skłanianie się ku bardziej merytorycznemu podejściu: rozwiązywaniu problemów przez niezależnych ekspertów. To przejście od tradycyjnej polityki, pojmowanej jako przestrzeń sporów i konfliktów ideologicznych czy walki politycznej ugrupowań o wyrazistych programach, do apolitycznej polityki rozumianej jako wyjście poza ideologiczne podziały polityczne na prawicę i lewicę (zacieranie różnic głównych nurtów ideologicznych) określane jest $\mathrm{w}$ kategoriach postpolityki ${ }^{4}$ (przejścia od tradycyjnej nowoczesnej polityki w kierunku polityki ponowoczesnej).

Drugie zderzenie (krótkie spięcie) pojawia się zwykle na styku dyskursów naukowych/teoretycznych i praktyczno-politycznych, co wymaga od nas pojęciowego rozróżnienia tych paradygmatów. Zdaniem Joego Wallisa i Briana Dollery'ego (1999):

Paradygmaty praktyczno-polityczne wywodzą się z paradygmatów teoretycznych, ale charakteryzują się znacznie mniej wyszukanymi i rygorystycznymi wymogami co do swojej intelektualnej konstrukcji, tworzącej ich ramy konceptualne. W literaturze przedmiotu dokonuje się rozdzielenia paradygmatów praktyczno-politycznych i teoretycznych, pomijając (screening out) wieloznaczności i zamazując wyrafino-

${ }^{3} \mathrm{Na}$ temat różnicy między politycznością a upolitycznieniem zob. artykuł Mirosława Karwata Polityczność i upolitycznienie [2010]. Popularny, obiegowy wręcz termin „upolitycznienie” traktowany jest zazwyczaj jako wyrażenie potoczne, dogodny skrót myślowy, często stosowany kontekstowo w analizach życia politycznego, niejako bez zobowiązań. Może być jednak przedmiotem analizy złożonego, wielokontekstowego mechanizmu współzależności między polityką a zjawiskami formalnie niezaliczanymi do jej zakresu (relacje między polityką a gospodarką, kulturą symboliczną czy twórczością artystyczną, wpływem mediów, życiem prywatnym jako wyraz narastającej tendencji do przenikania polityki do wszystkich dziedzin życia).

4 Sztandarowym przykładem takiej polityki była ,trzecia droga” Tony’ego Blaira czy „Agenda 2000" Gerharda Schroedera - nie zapominając o najbardziej znanej publikacji głównego ideologa „trzeciej drogi” Anthony’ego Giddensa Poza lewica i prawica [2001]. 
wane różnice znaczeniowe (fine distinctions), charakterystyczne dla paradygmatów teoretycznych [cyt. za: Jessop, 2007: 8]5.

Użycie tego rozróżnienia pomaga nam zrozumieć, że zainteresowanie polityką, politycznością czy postpolityką ma zarówno praktyczne, jak i teoretyczne korzenie oraz że przenoszenie idei czy argumentów między tymi dwoma typami paradygmatów czy dyskursów jest nie tylko niewskazane, ale może stanowić przedmiot poważnych uproszczeń i nieporozumień czy niejasności terminologicznych.

Jak podkreślaliśmy wcześniej, definiowanie i rozumienie polityki czy postpolityki jest wieloznaczne i często nieokreślone nie tylko w kontekście dyskursów potocznych czy praktyczno-politycznych, ale również teoretycznych. Komentując pierwsze międzynarodowe seminarium z dziedziny rozważań nad semantyką w nauce o polityce, które odbyło się w 1986 roku w Essen, Franciszek Ryszka [1988: 133] pisał, że uczestnicy ,zgodzili się, że istnieje znaczna i rosnąca dowolność w definiowaniu samego terminu «polityka», wynikająca głównie z doświadczeń i tradycji historycznych”, ale też nieporozumień związanych z ,pomieszaniem definicji semantycznych z kontekstowymi, przy nadużywaniu tych ostatnich".

Podejście do polityki (definiowania i rozumienia pojęcia polityki) ${ }^{6}$ jest ujęciem dynamicznym, ewoluującym w czasie i w głównej mierze zależy od tradycji i historii (podobnie jak społeczeństwo i wartości, które je przenikają i podlegają dynamice, ewoluują również dyskursy czy narracje o/w polityce). Dynamikę społeczeństwa i jej znaczenia doskonale oddaje przytoczony niżej fragment artykułu:

Kiedy polityka była pojmowana przede wszystkim jako walka wykluczających się systemów, czy walka klas na śmierć i życie, kwestie osobiste nie miały prawie żadnego znaczenia. Liczyło się to, kto jaką partię reprezentuje i jaka jest ideologia tej partii. To były podstawowe punkty orientacyjne. Wszystko zmieniło się pod koniec XX wieku. Upadek ideologii wytworzył bardziej prywatne spojrzenie na politykę. Obfitość różnych afer, będąca wynikiem nie tyle upadku wartości moralnych, co rosnącej przejrzystości, ujawnia nam hegemonię polityki skandalu. Politycy zrozumieli tę sytuację, poszukując medialnej formuły na swoje istnienie, czyniąc z reżyserowanego życia prywatnego kluczowy element własnej wiarygodności. [...] Liczni obserwatorzy światowej polityki twierdzą, że wkroczyliśmy w nową ,post-polityczną erę”, w której tradycyjne różnice ideowe nie mają żadnego znaczenia [Dybel, Wróbel, 2008: 18].

${ }^{5}$ Por. także opinię tych samych autorów: „W rozumieniu Lakatosa, paradygmaty praktyczno-polityczne mogą zostać uznane za pozytywne heurystyki, wywiedzione z paradygmatów teoretycznych. Przechodzenie od jednego do innego paradygmatu praktyczno-politycznego nie oznacza ciągłości, wynikającej z podążania za zmianą paradygmatu teoretycznego, i zdarza się częściej niż w odniesieniu do paradygmatów teoretycznych, gdyż to pierwsze przejście nie wymaga fundamentalnych zmian negatywnej heurystyki” [cyt. za: Jessop 2007: 8].

${ }^{6}$ Szerszą refleksję na temat współczesnych problemów związanych z definicją polityki podjął w książce Tyrania złudzeń. Studia z filozofii polityki Stefan Opara. Zwrócił uwagę na duży chaos w tej materii i uporządkował wiele popularnych akademickich sposobów ujmowania tego zagadnienia, wyodrębniając pięć podejść badawczych, cztery kierunki definiowania i trzy koncepcje polityki [Opara, 2009: 19-23]. 
Jak widać w kontekście przy toczonego cytatu, tradycyjne definiowanie i rozumienie polityki jako walki wykluczających się systemów (ideologicznych), uwikłanych w obiektywną sprzeczność interesów (społecznych), ma głównie podłoże aksjologiczne i kolektywne, oparte na modernistycznej wizji polityki ściśle powiązanej z państwem. Tymczasem definiowanie i rozumienie postpolityki związanej z ponowoczesnością wyraźnie wskazuje na odejście od zderzenia odmiennych systemów ideologicznych (definiowanych w kategoriach dobra publicznego) na rzecz bardziej pragmatycznego i indywidualistycznego ujęcia: zderzenia odmiennych interesów (definiowanych głównie w kategoriach dobra prywatnego), przy uwzględnieniu wpływu globalnych procesów (gospodarczych, społecznych i kulturowych), które znacznie wykraczają poza władzę czy kontrolę państwa.

\section{Polityka, postpolityka a polityczność}

Wydaje się, że ta swoista ambiwalencja czy napięcie między polityką a postpolityką stają się zasadnicze dla pogłębionej refleksji na temat definiowania i rozumienia pojęcia polityki i polityczności w ponowoczesności. Pojęcie postpolityki, które zdominowało współczesny dyskurs naukowy czy publiczny, pojawia się zasadniczo w dwóch kontekstach. Pierwszy, związany z rozdzieleniem władzy i polityki (usunięciem z dyskursu politycznego pojęcia polityczności), często bywa analizowany jako rezultat globalnych procesów przenoszenia władzy z poziomu państw narodowych na poziom ponadnarodowy. Drugi dotyczy procesu odideologizowania polityki (końca ideologii) na rzecz bardziej pragmatycznego czy konsensualnego podejścia do uprawiania polityki i rozwiązywania konfliktów społecznych.

Jako jeden z pierwszych uwagę na ten problem zwrócił Carl Schmitt ${ }^{7} \mathrm{w}$ kontekście liberalnej idei nowoczesnego państwa, która doprowadziła do rozdzielenia władzy i polityki: negacji państwa na rzecz prawa (zastąpienia władzy suwerena lub państwa rządami abstrakcyjnych norm). Schmitt podkreśla, że racjonalny postulat zniesienia podmiotowej władzy polityki i zastąpienia jej rzeczową władzą ekonomiki jednoczy przedstawicieli wielu grup społecznych, pomijając przy tym „konieczność moralnej decyzji, czyli istotę politycznej idei” [Schmitt, 2000: 46-47]. Dla Schmitta „naturą polityczności jest konflikt między wrogiem a przyjacielem" odnoszony do kategorii zbiorowości, który z jednej strony stanowi zagrożenie dla życia lub formy życia zbiorowości, z drugiej zaś ,,jest koniecznym warunkiem samookreślenia, integracji i uzyskania wspólnej tożsamości,

7 Carl Schmitt filozofię polityki (nazywaną przez niego „filozofią państwa” czy „teorią polityki”) rozumiał jako metafizykę polityki, a nie etykę polityczną. Nie chodziło mu o normatywne postulaty, lecz o opis i analizę polityki jako szczególnego rodzaju bytu; nie o to, jak być powinno w polityce $\mathrm{z}$ moralnego punktu widzenia, ale o to, jaka jest istota polityki, o sposoby jej istnienia, o pozycję polityki wśród innych dziedzin ludzkiego życia oraz stosunek bytowy między jednostką a wspólnotą polityczną. Zdaniem Schmitta każda refleksja o polityce zakłada przyjęcie jakiegoś stanowiska w kwestii natury ludzkiej: jej przyrodzonej dobroci lub pierwotnego i nieusuwalnego naznaczenia złem. Utrzymywał, że prawdziwa jest myśl polityczna, która opiera się na założeniu pesymizmu antropologicznego, a fałszywa - na założeniu optymizmu antropologicznego. 
świadomości tego, że jest się grupą, która prowadzi wspólny styl życia, któremu wróg zagraża" [Schmitt, 2000: 198-200]. Jak widać, rozumienie polityczności u Schmitta nie jest ujęciem przedmiotowym (nie odnosi się do obszaru statycznego czy czasowo-przestrzennego przedmiotu), ale podmiotowym (relacyjnym), dotyczy bowiem relacji na poziomie zbiorowym - wypływa z natury człowieka i opiera się na dynamicznym stosunku między jednością a różnicą (sprzymierzanie się z jednymi przez odróżnianie się od innych, uznanych za wrogów). Zdaniem Schmitta autonomia polityczności wynika z tego, że nie daje się sprowadzić do wyborów czy rozróżnień dokonywanych w innych obszarach życia, tj. dobrozło (moralność), piękno - brzydota (estetyka), zysk - strata (ekonomia), sacrum profanum (religia). Owa autonomia nie jest absolutna, ponieważ początkiem polityczności są różnice czy konflikt, które pojawiają się w innych obszarach na tyle silnie, że przeradzają się w konflikt/konflikty o wymiarze egzystencjalnym. W rezultacie wszystko jest potencjalnie politycznie, jednak tak rozumiana polityczność nie może być rozwiązana na drodze dyskusji, umowy czy kompromisu, ale na drodze konfrontacji czy walki (konfliktu o charakterze antagonistycznym).

Tematyka ta została podjęta przez Chantal Mouffe ${ }^{8}$, która nawiązując do odmiennego definiowania i rozumienia polityki i polityczności w ramach paradygmatów czy dyskursów teoretycznych i praktyczno-politycznych, dokonuje wyraźnego rozróżnienia między polityką a politycznością: ,,przez polityczność rozumiem wymiar antagonizmu leżący u podstaw każdego ludzkiego społeczeństwa, przez politykę natomiast zestaw praktyki instytucji, które w obliczu prowadzonego przez polityczność konfliktu tworzą porządek umożliwiający ludzkie współistnienie" [Mouffe, 2008: 24]. Zdaniem belgijskiej myślicielki współczesny brak zrozumienia aktualnych problemów politycznych wynika głównie z pragmatycznego podejścia do polityki (które koncentruje się na „ontycznym poziomie analizy”), tymczasem to „właśnie brak rozpoznania polityczności w jego ontologicznym wymiarze leży u podstaw współczesnej niezdolności do myślenia w sposób polityczny"9 [Mouffe, 2008: 23]. Dla Mouffe jako filozofa polityki w nurcie poststrukturalistycznym zarówno podmiotowość (indywidualna), jak i polityka (która odnosi się do tożsamości zbiorowych) mają charakter relacyjny czy podmiotowy, opierają się na różnicy i tożsamości. Różnica jest tutaj warunkiem bycia i identyfikacji, podstawą konstytuowania tożsamości - zarówno indywidualnych

${ }^{8}$ Chantal Mouffe uznaje się za filozofa polityki, który w sposób znaczący odnosi się do kwestii praktyki politycznej, oraz współtwórczynię (wraz z Ernestem Laclauem) teorii „,demokracji radykalnej”, definiującej filozofię polityki jako teorię dyskursu w nurcie poststrukturalizmu i dekonstrukcji. Istotą tego podejścia, które odrzuca obiektywizm i esencjalizm, jest założenie, że społeczeństwo (społeczna podmiotowość, tożsamość zbiorowa) jest pozbawione istoty, pełni, całkowitej trwałości i stabilności. Każdy ład konstytuuje się bowiem jako przygodny, tymczasowy i nietrwały, ale względnie ustabilizowany porządek symboliczny i jest polem dyskursywności.

${ }^{9}$ „Chcąc wyrazić to językiem filozofii, możemy, używając słownictwa Heideggera, powiedzieć, że polityka odnosi się do poziomu «ontycznego», podczas gdy polityczność dotyczy poziomu ontologii. Oznacza to, że analiza poziomu ontycznego stawia w centrum zróżnicowane praktyki polityki konwencjonalnej, analiza poziomu ontologicznego dotyka zaś samego sposobu, w jaki stanowione jest społeczeństwo" [Mouffe, 2008: 23]. 
(inność konstytuuje tożsamość jako „konstytutywne zewnętrzne”), jak i zbiorowych (konstytuowanie „my” dokonuje się przez odróżnienie od „oni”). Mouffe poszerza Schmittowskie ujęcie polityczności jako konfliktu czy relacji wyłącznie antagonistycznej, w którym obie strony stanowią swoje całkowite przeciwieństwo i nie podzielają żadnych fundamentalnych założeń, definiuje przy tym konflikt jako relację agonistyczną ${ }^{10}$, k której „,strony są świadome niemożliwości zaistnienia racjonalnego rozwiązania dzielącego je konfliktu, jednak uznają jednocześnie prawomocność swoich przeciwników" [Mouffe, 2008: 35]. Wprowadza tym samym kategorię przeciwnika, który w pewnym sensie pozostaje wrogiem, ale wrogiem posiadającym legitymację, takim, z którym dzieli się pewne fundamentalne założenia - przeciwnicy są ze sobą w konflikcie, łączy ich jednak przywiązanie do etyczno-politycznych podstaw demokracji liberalnej.

Zarówno Schmitt, jak i Mouffe podkreślają, że to właśnie liberalizm wraz z jego racjonalistycznym $\mathrm{i}$ indywidualistycznym podejściem jest odpowiedzialny za negację wymiaru polityczności w praktyce politycznej. Konsekwentny indywidualizm, który wymaga, by jednostka pozostała dla siebie ostatecznym punktem odniesienia, musi ich zdaniem negować wymiar polityczności, podobnie jak założenia „refleksyjnej nowoczesności” o racjonalnym konsensusie. Co więcej, liberalizm nie jest zdolny do uchwycenia wspólnotowego wymiaru życia społecznego (uniemożliwia rozpoznanie złożonej natury zbiorowych tożsamości, będących podstawą polityczności) czy pluralistycznej natury świata wraz z wielością prezentowanych perspektyw, wartości i konfliktów, których pogodzenie jest trudne, jeśli nie niemożliwe, ze względu na ograniczenia rzeczywistości [Mouffe, 2015: 19]. Liberalne podejście nadało sferze publicznej neutralny charakter, kosztem zepchnięcia wszelkich antagonizmów do poziomu prywatności, co w konsekwencji umożliwiło i zagwarantowało polityczny konsensus w formie politycznego centrum (demokracji konsensualnej), poza dotychczasowymi ideologicznymi podziałami politycznymi, przez co wiele grup społecznych nie znajduje obecnie swojej reprezentacji. Schmitt podkreśla, że „myśl liberalna systematycznie i konsekwentnie lekceważy lub pomija państwo oraz politykę, natomiast z uporem nawiązuje do dwóch, wyraźnie spolaryzowanych, heterogenicznych sfer: etyki i gospodarki świata duchowego i świata interesów, do wiedzy i własności" [Schmitt, 2000: 241].

W rezultacie tradycyjny dyskurs polityczny o charakterze ideologicznym został dziś zastąpiony przez postpolitykę oraz dwa liberalne paradygmaty czy dyskursy: ekono-

${ }^{10}$ Przez włączenie pojęcia „konstytutywne zewnętrze”, które nie jest dialektycznym przeciwieństwem my/wewnątrz, ale raczej warunkiem jego zaistnienia (współistnienia), w konstytuowanej tożsamości (indywidualnej i zbiorowej) pojawiają się zarówno wspólne płaszczyzny porozumienia, jak i konfliktu. Te rozważania na temat poszerzenia możliwości rozumienia opozycji my/oni są niezbędnym warunkiem pogodzenia tezy o nieusuwalności antagonizmu, przy jednoczesnej afirmacji możliwości demokratycznego pluralizmu. W przeciwnym razie pozostają dwie możliwości: przyjęcie za Schmittem tezy o wewnętrznej sprzeczności liberalnej demokracji (uznajemy polityczność, ale odrzucamy pluralizm demokratyczny) lub akceptacja liberalnej tezy o potrzebie wyeliminowania antagonizmu (odrzucamy polityczność na rzecz antypolityczności liberalnej demokracji) [Mouffe, 2008: 34]. 
miczny i estetyczno-moralny z towarzyszącym im przekonaniem o „końcu historii” i brakiem alternatywy (There Is No Alternative - TINA) w związku z osiągniętym poziomem rozwoju zachodnich demokracji liberalnych. Dyskurs ekonomiczny (modernizacyjny czy agregatywny) definiuje politykę jako budowanie racjonalnego kompromisu między rywalizującymi w obrębie społeczeństwa siłami i przedstawia jednostki jako istoty racjonalne dążące do maksymalizacji własnych korzyści, działające w świecie politycznym instrumentalnie. W rezultacie polityka jako przestrzeń sporów czy konfliktów ideologicznych zostaje zastąpiona przez technokratyczne zarządzanie, które odwołuje się do prymatu racjonalnego i merytorycznego (eksperckiego) podejścia do rozwiązywania aktualnych problemów ekonomiczno-społecznych. Doskonałym przykładem takiego paradygmatu jest tzw. nowe zarządzanie publiczne (New Public Management) ${ }^{12}$, które podporządkowując się ekonomii, zgodnie z zasadą „trzech E” (economy - ekonomiczność, efficiency - skuteczność, effectiveness - efektywność) uznaje prymat ekonomii nad polityką, przedkładając wartości ekonomiczne (tj. efektowność, skuteczność czy konkurencyjność) nad sprawy polityczne (tj. godzenie konfliktów społecznych). Jednym z podstawowych założeń Nowego Zarządzania Publicznego jest przekonanie, że obywateli należy włączać w zarządzanie publiczne, rozumiane jednak nie jako aktywizacja społeczna czy partycypacja polityczna, ale bardziej jako indywidualistyczne podejście do obywatela jako „konsumenta”.

Dyskurs deliberacyjny z kolei powstał jako reakcja przeciw modelowi instrumentalnemu i jest nastawiony głównie na tworzenie powiązań między polityką a moralnością, przedstawiając debatę polityczną jako szczególny obszar zainteresowania moralności. Zastępując racjonalność instrumentalną racjonalnością deliberacyjną (komunikacyjną), zakłada, że dzięki swobodnej dyskusji można osiągnąć w polityce racjonalny i moralny konsensus. W rezultacie polityka jest rozumiana nie na podobieństwo ekonomii, ale raczej moralności czy etyki - jak pisze Mouffe [2000: 20], ,polityczność jest dziś rozgrywana w rejestrze moralności”. Innymi słowy, nadal opiera się na rozróżnieniu my/oni, tyle że definiowanym nie w kategoriach politycznych, lecz w języku moralnym. Miejsce konfliktu ,prawicy z lewicą" (right and left) zajmuje walka „dobra ze złem” (right and wrong) dlatego w tej retoryce często pojawiają się hasła demokracji proceduralnej, demokracji partycypacyjnej czy społeczeństwa obywatelskiego w kontekście coraz bardziej współzależnego globalnego świata. Mouffe wyraźnie przestrzega przed

11 Kluczowa w tym kontekście ma być słynna teza Francisa Fukuyamy dotycząca końca historii. Fukuyama w swej głośnej książce Koniec historii z 2009 r. wyłożył koncepcję, wedle której historia to zmierzający w określonym kierunku uporządkowany i logiczny proces. Po osiągnięciu najbardziej zaawansowanego poziomu, ma się on zakończyć - w wymiarze politycznym na liberalnej demokracji, w wymiarze gospodarczym zaś na systemie wolnorynkowym.

12 Więcej na temat New Public Management zob.: Huges, 1994; Zalewski, 2006; Hausner, 2008; Zawicki, 2011; Szcześciło, Bełdowski, 2014. Najbardziej znanym przykładem NPM są cztery modele nowego zarządzania publicznego, których twórcami są Ewan Ferlie, Lynn Ashburner, Louise Fitzgerald oraz Andrew Pettigrew (1996): model NPM 1 - zwiększanie efektywności, model NPM 2 ograniczenie rozmiarów organizacji i decentralizacja zarządzania, model NPM 3 - w poszukiwaniu doskonałości, model NPM 4 - orientacja na usługi publiczne. 
rozgrywaniem polityki w sferze etycznej, czy - mówiąc inaczej - przed uprzywilejowaniem perspektywy etycznej względem politycznej, bowiem „rygorystyczna etyka bezwarunkowości jest sprzeczna z domeną polityki, która zawsze ma do czynienia z tym, co warunkowe" i często przedstawiana jest jako wyższy i jedynie słuszny porządek [Mouffe, 2015: 31]. Tymczasem demokratyczna polityka powinna raczej konfrontować różne projekty hegemoniczne, które są uznawane za przygodne i często poddawane kontestacji, bez możliwości osiągnięcia ostatecznej zgody.

\section{Polityka a ekonomia polityczna (hegemonia dyskursu neoliberalnego)}

Pytanie o współczesne rezultaty uprawiania tak rozumianej postpolityki, które w Europie Zachodniej towarzyszą nam od lat siedemdziesiątych XX wieku, odsyła nas z powrotem do Chantal Mouffe, która wyraźnie przestrzega nas przed rosnącym radykalizmem czy populizmem ruchów społecznych, wynikającym z tego, że „wyborcy nie mają możliwości identyfikować się ze zróżnicowanym przekrojem demokratycznych tożsamości politycznych. Tworzy to pustkę, łatwą do wypełnienia przez inne formy identyfikacji, które mogą stać się problematyczne dla działania demokratycznego" [Mouffe, 2008: 86]. W podobnym tonie o postpolityce wypowiada się Słavoj Žižek, który uważa, że ,radykalizacja polityki [...] widoczna $\mathrm{w}$ różnych postaciach fundamentalizmu jest formą, jaką przyjmuje wykluczona polityczność, wracając do postpolitycznego uniwersum pluralistycznych negocjacji i konsensualnej regulacji” [Žižek, 2011b: 48]. W rezultacie ,jedynym sposobem na przeciwstawienie się tym radykalnym wybuchom polityki nie jest więcej tolerancji, współczucia czy wielokulturowego porozumienia, ale wręcz przeciwnie - powrót do właściwego wymiaru polityczności, z którego uniwersalność nie jest wykluczona, ale z którym jest współistotna" [Žižek, 2011b: 48]. Obydwoje - i Mouffe, i Žižek - zgadzają się co do tego, że postpolityka ze swoim pasywnym sposobem prowadzenia polityki i dążeniem do konsensusu za wszelką cenę, odwołująca się do „końca historii” i wiary w kres ideologicznych sporów w polityce, które sama uważa nie tylko za błędne, ale i niebezpieczne, (odd)daje tym samym pole działania czy przestrzeń dyskursu populistycznym bądź radykalnym ruchom, wyrastającym na fali społecznej tęsknoty za wyraźnym programem politycznym. W rezultacie polityka „,zamiast stać się areną agonicznej debaty między perspektywami lewicowymi a prawicowymi, ogranicza się do «kręcenia kołowrotkiem» (spinning)" [Mouffe, 2008: 79], odnoszonym bardziej do mediatyzacji dyskursu politycznego, który staje się nieodłączną cechą demokracji w dobie społeczeństwa medialnego, wyznaczając tym samym nowe relacje i zależności między polityką a mediami ${ }^{13}$.

${ }_{13}$ Więcej na temat nowych relacji i zależności między polityką a mediami w dobie społeczeństwa medialnego zob. Zdański, 2009. Teoretycy dzielą władzę mediów na wiele sposobów, np. John Street wyróżnia trzy rodzaje władzy: dyskursywną (opiera się na założeniu, że rzeczywistość kon- 
W społeczeństwie medialnym coraz więcej elementów ze świata realnego rozgrywa się głównie w mediach, przez co polityka staje się bardziej widowiskiem czy spektaklem medialnym. Postpolityka doskonale koegzystuje z mediatyzacją, ułatwia bowiem przeniesienie każdej dyskusji politycznej z poziomu rzeczywistych konfliktów i kryzysów (hard news) na poziom medialnego spektaklu, który ogniskuje się na pozornych lub zastępczych konfliktach, zamieniając debatę polityczną w polityczną rozrywkę (politainmnet/soft news) przedstawianą $\mathrm{w}$ formie sensacji, afery czy skandalu (szokowania odbiorców). Równoległym procesem towarzyszącym postpolityce jest tzw. tabloidyzacja (zarówno dyskursu politycznego, jak i sceny politycznej), która zdaniem Doroty Piontek [2011: 202] przejawia się głównie w formie prezentowania fragmentarycznych wypowiedzi polityków komentujących zachowania (czy działania) innych polityków (ad personam), a nie bieżące problemy czy wydarzenia. To zbliża politykę bardziej do tabloidalnego rankingu popularności (tabloidalnego produktu dla tabloidowych konsumentów). $\mathrm{W}$ rezultacie tradycyjną politykę zastępuje marketing polityczny, który jest częścią ,demokracji spektaklu”, pośrednio uzasadniając i legitymizując model polityki, w którym od treści i politycznej wizji ważniejsze są forma i medialne przedstawienie, zaś klasę polityczną zastępuje klasa polityczno-medialna [Żuk, 2006: 11]. Jak zauważa Eryk Mistewicz:

[...] w świecie postpolityki emocje zajęły miejsce programów wyborczych, a wizerunek zdystansował idee. W tym świecie rządzą dobrze przygotowane, profesjonalne opowieści, omijające banał, rozumiejące emocje, nie ideologie i programy. Zanikły wielkie projekty czy ambitne cele. Przestały być ważne partie, nawet parlamenty [Mistewicz, 2011: 68].

Bezpośrednim rezultatem tak rozumianej postpolityki jest rosnący kryzys zaufania do polityki i polityków (kryzys władzy), który po części stanowi konsekwencję takiej praktyki politycznej, określanej jako brak odpowiedzialności lub „zinstytucjonalizowana nieodpowiedzialność"14, w dużym stopniu wynika jednak z obrazu elit politycznych, wytwarzanych i upowszechnianych przez media. Iwan Krastew, analizując w Demokracji nieufnych z 2013 roku przyczyny współczesnego kryzysu zaufania do demokracji i polityki, pisze o utracie poczucia kontroli nad polityką i gospodarką, o przeświadczeniu, że wszystko jest przesądzone i w zasadzie nic od nas nie zależy, przez co obywatelom pozostaje jedynie rola widza rozgrywającego się przed nim medialnego spektaklu politycznego, który

stytuowana jest przez dyskurs - władzę ma ten, kto kontroluje dyskurs), dostępu (kontrola treści, które w dyskursie mogą się pojawić) i zasobów (możliwość wpływania na rządy i państwa, które potrzebują usług medialnych koncernów) [Street, 2006: 200].

${ }^{14} \mathrm{~W}$ raporcie Państwo i My. Osiem grzechów głównych Rzeczypospolitej wydanym w 2015 roku autorzy sugerują, że sferę polityki zdominowała „zinstytucjonalizowana nieodpowiedzialność”, czyli przerzucanie się odpowiedzialnością na linii klasa polityczna - administracja - społeczeństwo, tak że ostatecznie nie wiadomo, kto za co odpowiada. Urzędnicy nie ponoszą osobistej odpowiedzialności za decyzje administracyjne, w polityce dominuje cynizm i technokracja, czyli podpieranie się ekspertyzami specjalistów od PR-u, brakuje zaś wyobraźni strategicznej i misyjnego podejścia do rządzenia [Fundacja Gospodarki i Administracji Publicznej, 2015]. 
nie oferuje nic poza oburzeniem czy znużeniem. Skutkiem tego rosnącego braku zaufania do polityki i polityków jest ucieczka w cynizm lub prywatność - wyborcy być może mają wpływ na wybór (zmianę) polityków, ale już nie na wybór (zmianę) polityki (zwłaszcza polityki gospodarczej, za którą stoją globalni gracze, w której rezultacie rynek staje się hegemonem ponad państwem).

Obecnie znaleźliśmy się w dość szczególnym momencie historii, w którym powraca pytanie o możliwą kompatybilność czy koegzystencję demokracji i liberalizmu - liberalizm stracił na dobre swój mit założycielski, który pozwolił mu stać się dominującą ideologią nowoczesnego państwa ${ }^{15}$. Doszliśmy do momentu, w którym niekompatybilność liberalizmu (głównie gospodarczego) z demokracją stała się nie do ukrycia, nie tylko ze względu na sprzeczności ideologiczne, ale również, a może przede wszystkim - ze względu na sprzeczności strukturalne, powiązane $z$ dynamicznymi i przez to trudnymi do przewidzenia procesami globalnych przemian współczesnego świata.

Ten konflikt został opisany przez Daniego Rodrika w Paradoksie globalizacji z 2011 roku jako trylemat globalizacji: konflikt między demokracją (demokratycznym systemem zarządzania państwem), niczym nieograniczoną globalizacją gospodarczą (hiperglobalizacją opartą na paradygmacie neoliberalnym) oraz autonomią czy suwerennością państw, zwłaszcza w kontekście polityki społecznej czy gospodarczej. Zdaniem Rodrika ten paradoks jest niemożliwy do pogodzenia na poziomie państwa narodowego, można co najwyżej połączyć dwa z trzech wyżej wymienionych celów politycznych - hiperglobalizacja jest możliwa albo w wypadku ustanowienia jakiejś formy rządu światowego (globalny federalizm), albo po rezygnacji z demokracji na rzecz sterowania państwem przez technokratyczne elity, dostosowujące swoją politykę do wymogów rynku światowego (a nie oczekiwań obywateli). Ponieważ pierwsza opcja nie jest realistyczna, a druga nie do zaakceptowania ze względów moralnych, pozostaje rezygnacja z hiperglobalizacji - demokracja powinna odzyskać kontrolę nad rynkiem i gospodarką (przełamując dotychczasowa hegemonię ekonomii nad polityką).

W kontekście stale rosnącej dynamiki przemian współczesnych procesów globalnych można zaobserwować wyraźną dysproporcję między tempem i głębokością tych przemian a zdolnością do ich absorpcji czy kontroli przez dotychczasowe mechanizmy i instytucje polityczne. Jako rezultat hiperglobalizacji pojawiały się jakościowo odmienne globalne podmioty: nowe konfiguracje współzależnych i sprzecznych interesów, oligarchicznych sojuszy ponad podziałami czy agregacji ideologicznych, łączących interesy i wartości ekonomiczne, kulturowe i polityczne.

15 Oparty na szczególnej odmianie racjonalnego egoizmu zakorzenionego w systemie przetwarzającym owe (samolubne) indywidualistyczne dążenia na te korzystne dla całej społeczności z wykorzystaniem mechanizmów samoregulującego się wolnego rynku. W rezultacie w drugiej połowie XX wieku pojawiły się dość desperackie próby, by ratować jedne i drugie: $\mathrm{z}$ jednej strony, postliberalne wypaczenia w stylu Ayn Rand, które wobec bankructwa modelu racjonalnego egoizmu próbowały umocować etyczny wymiar egoizmu, z drugiej zaś teoretyczny ciężar habermasowskiej demokracji deliberatywnej, który dawał nadzieję na zamiecenie narastających sprzeczności pod dywan przez zmniejszenie wagi wyborów w procesie demokratycznym, legitymizując de facto zwolnienie liberalnej jednostki z obowiązku aktywnego uczestnictwa w życiu politycznym wspólnoty. 
Większość z nich ma charakter transnarodowy lub globalny o istotnym politycznie ciężarze gatunkowym (oligarchiczna autonomizacja partykularnych interesów transnarodowych korporacji). Toffler [2003], pisząc o współczesnych przemianach władzy, zwraca uwagę m.in. na kryzys (bezsilność) dotychczasowych instrumentariów tradycyjnej polityki wobec rosnącej złożoności i współzależności współczesnych problemów i wyzwań globalnych - zarówno w kontekście poznawczym (dezaktualizacja dotychczasowych „wyobrażeń”: heurystyk, naukowej refleksji, języka czy pojęć), jak i strukturalnym (ograniczenie polityki do poziomu makrostrukturalnego, głównie państwa i walki o władzę w państwie). Tego rodzaju logika (zamkniętych i hierarchicznych systemów) wydaje się dzisiaj nie tylko błędna, ale i nieadekwatna, zwłaszcza na tle dynamicznych przemian mezo- i mikrostrukturalnych, dokonujących się poza kanałami instytucjonalnymi w formie heterarchicznych, otwartych i płynnych konstelacji.

Co ciekawe, w tym kontekście rzadko (jeśli w ogóle) mówi się o władzy dyskursywnej (władzy nad znaczeniem) jako otwartej przestrzeni artykulacji problemów czy konfliktów: politycznych, społecznych bądź gospodarczych. Tymczasem wobec dokonującej się obecnie rewolucji informacyjno-komunikacyjnej czy ponowoczesnej mediatyzacji dyskursu oraz kulturowego stanowienia tożsamości czy „wyobrażeń” (indywidualnych i zbiorowych) to właśnie dyskursywna władza (przestrzeń dyskursu) jest konstytutywna dla naszych „wyobrażeń” o polityce, polityczności czy rzeczywistości. Jak mówiliśmy wcześniej, medialna przestrzeń dyskursu została zawłaszczona przez polityczno-medialną klasę, która koncentrując się głównie na formie i medialnym przedstawieniu, odchodzi od istotnych treści czy politycznej wizji (ideologii) - w rezultacie mamy do czynienia z coraz bardziej uproszczonymi (językowo, pojęciowo i merytorycznie) narracjami. Co więcej, ta sytuacja dotyczy nie tylko potocznych dyskursów, które pojawiają się w debacie publicznej, ale też dyskursów praktyczno-politycznych czy teoretycznych. Tymczasem jeśli chodzi o dyskurs naukowy, rzadko kiedy mówi się o ideologicznym czy politycznym wymiarze poszczególnych dyscyplin naukowych, zwłaszcza nauk ekonomicznych.

To maskowanie czy ukrywanie ideologicznego i politycznego wymiaru dyscyplin naukowych, przedstawianych często jako racjonalne i obiektywne czy apolityczne, jest wyrazem ideologicznego i politycznego zaangażowania nauki. Można odnieść wrażenie, że formalna abstrakcja neoklasycznej ekonomii wraz z jej modelami matematycznymi, wiarą w obiektywność epistemologiczną czy bezstronność naukowych metod weryfikacji może sugerować, że ekonomia jest dziedziną pozbawioną kontekstu ideologicznego czy kulturowego. Tego rodzaju założenie, choć często podzielane przez ekonomistów, jest jednak jedynie kolejnym uproszczeniem (redukcja epistemologiczna), bowiem jako paradygmat poznawczy czy dziedzina naukowa nie może być niezależne od kultury, podobnie jak nie może być wolne od wartościowania. Ekonomiści neoklasyczni nie przyjmują do wiadomości, że ich własne, jawne czy ukryte, systemy wartości wpływają na sposób, w jaki widzą i postrzegają świat oraz możliwe drogi jego rozwoju. W rezultacie odciskają się one na ich sposobie myślenia jeszcze mocniej, głównie dlatego, że nabyte czy odziedziczone wartości bądź wyobrażenia wywierają tym większy, bo niezauważalny (nieświadomy), wpływ na ich postawy, orientacje i działania. 
Dotyczy to w szczególności hegemonii neoliberalnego paradygmatu, który zdominował nie tylko współczesny dyskurs w ekonomii, ale również pozostałe obszary naszego życia, w tym przede wszystkim politykę, kulturę i sztukę czy relacje społeczne, dając podstawę legitymizacji i afirmacji aktualnego systemu społeczno-ekonomicznego i politycznego, w tym również struktur panowania i dominacji (hegemonii). Ukrywając swoje prawdziwe oblicze, staje się fundamentem reprodukcji hegemonii ideologicznej, głównie przez środki masowego przekazu, edukację, kulturę lub stosunki w środowisku pracy, uniemożliwiając tym samym stawienie świadomego oporu (kontrhegemonicznych praktyk) i dokonanie własnego mniej lub bardziej świadomego wyboru sposobu, w jaki postrzegamy czy definiujemy otaczającą nas rzeczywistość.

W tym kontekście kluczowe wydaje się odwołanie do koncepcji kulturowej ekonomii politycznej Boba Jessopa [2008; Jessop, Sum, 2006] - kulturowa ekonomia polityczna, łącząc pojęcia i narzędzia z krytycznej analizy semiotycznej i krytycznej ekonomii politycznej, podkreśla w sposób szczególny znaczenie czynnika kulturowego w ekonomii politycznej, przez co stwarza możliwość do postdyscyplinarnego spojrzenia zarówno na sferę ekonomiczną i polityczną, jak i sferę społeczną czy kulturową. Podchodząc poważnie do roli i znaczenia kultury, „kładzie nacisk na złożone relacje między znaczeniem a użyciem, jako że generowanie znaczenia intersubiektywnego jest niezbędne w opisie, rozumieniu i wyjaśnianiu działań ekonomicznych i politycznych w tym samym stopniu, w jakim nieodzowne jest ono w innych typach zachowań społecznych" [Jessop, 2008: 123]. Odwołując się do kluczowego pojęcia wyobrażeń (imaginaries), możemy przyjąć, że wyobrażenie jest rodzajem konceptualnej ramy (paradygmatu), sposobu, w jaki postrzegamy otaczającą nas rzeczywistość, istotnym dla naszej zdolności funkcjonowania w świecie. Zdaniem Jessopa [2007: 13], jak już wspomniano, tak naprawdę nie jesteśmy w stanie objąć percepcyjnie w czasie rzeczywistym całej złożoności świata i wszystkich jego współzależności ${ }^{16}$, stąd nasza potrzeba upraszczania lub redukowania, które pozwalają na zrozumienie czegokolwiek i lepsze lub gorsze funkcjonowanie w świecie. W rezultacie naszym działaniem w świecie kierują idee czy wyobrażenia, a nie rzeczywistość - do rzeczywistości jako takiej nie mamy dostępu. Kulturowa ekonomia polityczna podkreśla, że zwykle dokonujemy uproszczeń czy redukcji przez przyjęcie określonych koncepcji, ideologii lub wyobrażeń, które funkcjonują na poziomie społecznej świadomości. Właśnie do tego potrzebne nam są ideologie, problem w tym, że zwykle między ideą/ideologią a rzeczywistością pojawiają się poważne luki (nieciągłości, niejasności, nieścisłości).

16 „Ontologiczna kompleksowość oznacza, że świat jest zbyt złożony, aby kiedykolwiek umysł ludzki zdołał go ogarnąć [...]. Ponieważ kompleksowe całości (entities) i ich interakcje zawierają wiele naturalnie niezbędnych potencjalności (i możliwych stanów), które mogą nie być i/lub nie mogą być spełnione, w przypadku systemów kompleksowych występuje z zasady nieprzewidywalność i niedookreślenie ich funkcjonowania. To wyklucza użycie prostego algorytmu do generowania wyjaśnień złożonych zjawisk lub dostarczenia podstaw ich planowania i wymaga mechanizmów redukujących lub upraszczających kompleksowość na poziomie poznawczym, organizacyjnym i praktycznym” - pisze Nicholas Rescher [cyt. za: Jessop, 2007: 13]. 
Jessop wyraźnie podkreśla, że kiedy rośnie złożoność otaczającego nas świata, coraz trudniej jest nam zrozumieć rzeczywistość, dlatego zazwyczaj nie jesteśmy w stanie przewidzieć, co będzie się działo w przyszłości, nie mamy bowiem nawet dostępu do współczesności (teraźniejszości) w całej jej złożoności. W tej sytuacji wyobrażenia jako uproszczenia stają się groźniejsze, ale jednocześnie coraz trudniej się bez nich obejść, przez co powiększają się luki (niejasności, nieścisłości) między wyobrażeniem a rzeczywistością. Kiedy zmienia się rzeczywistość, a przyjęte wyobrażenia mimo wszystko nadal trwają, narastające sprzeczności czy napięcia stają się nie do wytrzymania, pojawia się potrzeba radykalnej zmiany, która znosi dotychczasowy porządek i ustanawia władzę nowych wyobrażeń. Kulturowa ekonomia polityczna podkreśla, że kryzysy głęboko zaburzają dominujące wyobrażenia, inspirując społeczeństwo do debaty na temat sposobów definiowania i ustanawiania społecznie przyjętych wyobrażeń (redukowania obrazów rzeczywistości) oraz radzenia sobie z ceną tych redukcji - niezwykle ważne jest, żeby te wyobrażenia zostały nazwane, żeby toczyła się między nimi dyskusja i żebyśmy rozumieli, co się stanie, kiedy okażą się nietrafne.

Co ważniejsze, taka debata pokazuje nam, jaki jest aktualny udział i rozkład sił w rozprzestrzenianiu i utrzymywaniu wyobrażeń. Niestety zwykle nie trafność idei decyduje o jej znaczeniu czy popularności, ale siła (interesów), która za nią stoi, co w sposób oczywisty pogłębia negatywne skutki uproszczeń czy wyobrażeń i bardziej zaciemnia, niż rozjaśnia obraz rzeczywistości. To jedynie potwierdza, że mimo powszechnego przekonania, że ekonomia czy polityka opierają się na wiedzy i informacji (evidence based policy), w praktyce okazuje się, że są wiedzą opartą na polityce (policy based evidence). W rezultacie i ekonomia (dominujący paradygmat neoliberalny), i polityka (dominująca współcześnie postpolityka) de facto stają się narzędziem (kulturowej) ekonomii politycznej.

W tym kontekście współczesny (permanentny) kryzys ekonomiczny, często określany jako kryzys systemowy (kryzys obowiązującego paradygmatu, a nie tylko kryzys w jego ramach), wraz z towarzyszącym mu kryzysem zaufania, zarówno do ekonomii, jak i polityki, coraz wyraźniej podważa (kwestionuje) hegemonię paradygmatu (neoliberalnego) nad polityką i innymi obszarami życia społecznego lub/i kulturowego. Otwiera tym samym nowe pola refleksji czy debaty publicznej, zmierzającej nie tylko do rozpoznania jego dotychczasowych granic, podstawowych sprzeczności czy mechanizmów ich podtrzymywania, lecz także do ich przekroczenia czy poszerzenia (poszukiwania alternatywnych wyobrażeń). W rezultacie pojawia się potrzeba wypracowania bardziej złożonego i wielokontekstowego wyobrażenia (paradygmatu) i powiązanych z nim dyskursów politycznych, opartych na pewne wpisanej weń immamentnej złożoności oraz ambiwalencji, które obejmują nie tylko wyobrażenia ekonomiczne, ale również społeczne i kulturowe. Tylko takie wyobrażenie jest w stanie oddać wielopodmiotowe i wieloaspektowe definicje polityki, uwzględniając zarówno kontekst czy pole strukturalne, relacyjne/behawioralne czy dyskursywne, jak i poziom indywidualny i zbiorowy czy też podejście przedmiotowe i podmiotowe, ideologiczne i pragmatyczne. W przeciwnym razie próba zatrzymania status quo, opartego na hegemonii neoliberalnego paradygmatu wraz z towarzyszącą mu postpolityką, 
jako dość ograniczone i jednowymiarowe podejście czy wyobrażenie polityki i gospodarki, przyczynia się jedynie do pogłębienia obecnego kryzysu ekonomicznego i politycznego, który wraz z obecnym kryzysem zaufania i rządzenia prowadzi w rezultacie do kryzysu państwa i demokracji oraz pojawienia się dylematów typu: co jest ważniejsze - liberalizm zajętych sobą (głównie gospodarczo) jednostek czy demokracja aktywnych obywateli?

\section{Bibliografia}

Czajkowski A. (2011), Polityka w pięciu odsłonach. Metatypologia zjawiska, „Wrocławskie Studia Politologiczne", 12, 5-25.

Dybel P., Wróbel S. (2008), Granice polityczności. Od polityki emancypacji do polityki życia, Aletheia, Warszawa.

Ferlie E., Ashburner L., Fitzgerald L., Pettigrew A. (1996), The New Public Management in Action, Oxford University Press, Oxford.

Fukuyama F. (2009), Koniec historii, tłum. T. Bieroń, M. Wichrowski, Znak, Kraków.

Giddens A. (2001), Poza lewica i prawica. Przyszłość polityki radykalnej, tłum. J. Serwański, Zysk i S-ka, Poznań.

Gulczyński M. (2009), Alternatywne orientacje w politologii, „Zeszyty Naukowe AlmaMer” $1(54)$.

Hausner J. (2008), Zarzadzanie publiczne, Scholar, Warszawa.

Huges O.E. (1994), Public Management and Administration: An Introduction, The Macmillan Press Ltd., London.

Jessop B. (2007), Promowanie „,dobrego rządzenia” i ukrywanie jego słabości. Refleksja nad politycznymi paradygmatami i politycznymi narracjami w sferze rządzenia, „Zarządzanie Publiczne" (Uniwersytet Ekonomiczny w Krakowie), 2(2), 5-25.

Jessop B. (2008), Kulturowa ekonomia polityczna a analiza dyskursu [w:] A. Duszak, N. Fairclough (red.), Krytyczna analiza dyskursu. Interdyscyplinarne podejście do komunikacji społecznej, Univesritats, Kraków.

Jessop B., Sum N.-L. (2006), Towards a Cultural International Political Economy [w:] M. de Goede (ed.), International Political Economy \& Poststructural Politics, Palgrave Macmillan, New York.

Karwat M. (2004), Polityka rzeczowa, stronnicza i metapolityka [w:] T. Klementewicz (red.) Wspótczesne teorie polityki - od logiki do retoryki, Studia Politologiczne, 8, Instytut Nauk Politycznych UW, Warszawa.

Karwat M. (2010), Polityczność i upolitycznienie. Metodologiczne ramy analizy, „Studia Politologiczne", 17, 63-88.

Krastew I. (2013), Demokracja nieufnych. Eseje polityczne, tłum. M. Sutowski, Wydawnictwo Krytyki Politycznej, Warszawa.

Lukes S. (2006), Władza w ujęciu radykalnym [w:] A. Jasińka-Kania, L.M. Nijakowski, J. Szacki, W. Zółkowski (red.), Współczesne teorie socjologiczne, Scholar, Warszawa.

Mouffe Ch. (2008), Polityczność. Przewodnik „Krytyki Politycznej”, tłum. J. Erbel, Wydawnictwo Krytyki Politycznej, Warszawa. 
Mouffe Ch. (2011), Wyzwanie Schmitta [w:] Ch. Mouffe (red.), Carl Schmitt. Wyzwanie polityczności, tłum. T. Leśniak [i in.], Wydawnictwo Krytyki Politycznej, Warszawa.

Mouffe Ch. (2015), Agonistyka. Polityczne myślenie o świecie, tłum. B. Szelewa, Wydawnictwo Krytyki Politycznej, Warszawa.

Opara S. (2009), Tyrania złudzeń. Studia z filozofii polityki, MUZA SA, Warszawa.

Piontek D. (2011), Komunikowanie polityczne i kultura popularna. Tabloidyzacja informacji o polityce, Wydawnictwo Naukowe Uniwersytetu im. Adama Mickiewicza w Poznaniu, Poznań.

Rodrik D. (2011), The Globalization Paradox: Democracy and the Future of the World Economy, W.W. Norton \& Company, New York-London.

Ryszka F. (1988), O tym co „polityczne”. Przyczynek do rozważań z semantyki politycznej [w:] K. Opałek, F. Ryszka, W. Sokolewicz (red.), Prawo i polityka, Państwowe Wydawnictwo Naukowe, Warszawa.

Schmitt C. (2000), Teologia polityczna i inne pisma, tłum., wstęp i wybór M.A. Cichocki, Znak, Warszawa.

Street J. (2006), Mass media, polityka, demokracja, tłum. D.T. Lubański, Wydawnictwo Uniwersytetu Jagiellońskiego, Kraków.

Toffler A. (2003), Zmiana władzy. Wiedza, bogactwo i przemoc u progu XXI stulecia, tłum. P. Kwiatkowski, Zysk i S-ka, Poznań.

Zalewski A. (2006), Teoria i praktyka nowego zarzadzania publicznego [w:] M. Ostaszewski, M. Zaleska (red.), W stronę teorii i praktyki finansów, Wydawnictwo Szkoły Głównej Handlowej, Warszawa.

Zawicki M. (2011), Nowe zarządzanie publiczne, Państwowe Wydawnictwo Ekonomiczne, Warszawa.

Zdański J. (2009), Demokracja $w$ dobie społeczeństwa medialnego [w:] M. Kolczyński, M. Mazur, S. Michalczyk (red.), Mediatyzacja kampanii politycznych, Wydawnictwo Uniwersytetu Śląskiego, Katowice.

Žižek S. (2011a), Lacrimae Rerum. Kieślowski, Hitchcock, Tarkowski, Lynch, tłum. G. Jankowicz [i in.], Wydawnictwo Krytyki Politycznej, Warszawa.

Žižek S. (2011b), Carl Schmitt w czasach postpolityki [w:] Ch. Mouffe (red.), Carl Schmitt. Wyzwanie polityczności, tłum. T. Leśniak [i in.], Wydawnictwo Krytyki Politycznej, Warszawa.

Żuk P. (2006), Wstęp. Demokracja spektaklu, czy przymus przez uwodzenie [w:] P. Żuk, Media $i$ władza, Scholar, Warszawa.

\section{Źródła internetowe}

Fundacja Gospodarki i Administracji Publicznej (2015), Państwo i My. Osiem głównych grzechów Rzeczypospolitej [raport], http://www.fundacja.e-gap.pl/raport.pdf [dostęp: 21.09.2016].

Mistewicz E. (2011), Idee nieważne, ważna władza, „Uważam Rze”, nr 4, http://erykmistewicz. pl/media/uwazam-rze/idee-niewazne-wazna-wladza-uwazam-rze/ [dostęp: 22.11.2017].

Szcześciło D., Bełdowski J. (2014), W strone nowego zarządzania publicznego, http://nawokandzie.ms.gov.pl/numer-4/opinie-4/w-strone-nowego-zarzadzania-publicznego.html [dostęp: 22.11.2017]. 